ACTA MYCOLOGICA

Vol. 44 (2): 239-248

2009
Dedicated to Professor Krystyna Czyżewska

in honour of 40 years of her scientific activity

\title{
Notes on Caloplaca lucifuga (Teloschistales, Ascomycota) in Poland
}

\author{
DARIUSZ KUBIAK ${ }^{1}$ and ANNA ZALEWSKA ${ }^{2}$
}

${ }^{1}$ Department of Mycology, Warmia and Mazury University in Olsztyn

Oczapowskiego 1A, PL-10-957 Olsztyn, darkub@uwm.edu.pl

${ }^{2}$ Department of Botany and Nature Protection, Warmia and Mazury University in Olsztyn

Plac Łódzki 1, PL-10-727 Olsztyn, annazalw@uwm.edu.pl

Kubiak D., Zalewska A.: Notes on Caloplaca lucifuga (Teloschistales, Ascomycota) in Poland. Acta Mycol. 44 (2): 239-248, 2009.

The current knowledge on the occurrence of Caloplaca lucifuga, a rare lichen with an inconspicuous crustose sorediate thallus, is discussed. Both previous and new localities are presented. The most important data on the ecology and general distribution of the species are given. Diagnostic characters related to the morphology, anatomy and chemistry of $C$. lucifuga that help to differentiate it from similar species are described.

Key words: lichenized fungi, sorediate species, Caloplaca, distribution, N Poland

\section{INTRODUCTION}

Caloplaca lucifuga belongs to a group of crustose, sterile sorediate lichens that are relatively poorly known in Poland (Nowak, Tobolewski 1975; Śliwa, Tønsberg 1995; Śliwa 1996; Kukwa 2005a, b, 2006; Kukwa, Szymczyk 2006; Kukwa, Kubiak 2007). Despite its small-sized thallus, this very rare species has distinct, characteristic morphological and chemical features that help to distinguish it from other similar taxa. Its special ecological requirements also make the species noteworthy. C. lucifuga is associated with the bark of old deciduous trees, especially oaks. It seems to have potential indicator properties that may be used to identify high-biodiversity sites and forest communities of special value for protection purposes (cf. Rose 1992; Arup 1997; Nordén et al. 2007).

Caloplaca lucifuga was first reported in Poland by Lipnicki (1993) from the Bory Tucholskie forest. Its localities were later noted in the Puszcza Borecka forest by Zalewska (2000) and in the Puszcza Białowieska forest by Sparrius (2003). Specimens of $C$. lucifuga were collected from the Puszcza Białowieska forest by H. Sipman and P. van den Boom as early as in 1988; however, the exact location of the 
sites is unknown (unpbl. data acc. to Sparrius 2003; Sparrius, pers. comm. 2009). Data on the occurrence of $C$. lucifuga in north-east Poland are provided in a study by Cieśliński (2003), who cites unpublished materials by J. Nowak from the Puszcza Białowieska forest.

The available scarce data on the distribution of Caloplaca lucifuga in Poland are given in this study and its new localities recorded in the Pojezierze Olsztyńskie lakeland are presented on the map.

Habitat requirements of $C$. lucifuga identified so far suggest that further localities of the species are likely to occur in Poland. The aim of the study was to present the species and to indicate the most important diagnostic characters that help to find it in field studies and to recognise it in herbarium materials.

\section{MATERIAL AND METHODS}

The material was collected in 1995-1997 and 2005-2008. Specimens were identified with standard morphological and anatomical methods as well as using spot colour reaction tests to differentiate secondary metabolites (Purvis et al 1992; Orange et al. 2001). The square number of the modified ATPOL grid (Cieśliński, Fałtynowicz 1993) was given for all localities. The nomenclature of lichens follows Fałtynowicz (2003) and Diederich et al. (2009). The material was deposited in the Herbarium of the Department of Mycology, Warmia and Mazury University in Olsztyn (OLTC-L) and in the Herbarium of the Department of Botany and Nature Protection, Warmia and Mazury University in Olsztyn (OLS-L).

\section{RESULTS}

Caloplaca lucifuga Thor, Lichenologist 20 (2): 175 (1988).

Morphology. Thallus endophloedic, inconspicuous or visible as a thin grey film with scattered small blisters. Photobiont chlorococcoid 7-14 $\mu \mathrm{m}$ diam., algal cells in clusters (in the thallus section). Soralia numerous, $0.15-0.35 \mathrm{~mm}$ in diam., forming by a break-up of blisters, pale yellow, yellowish grey to dirty yellow-orange-brown, delimited, but sometimes lying very close to one another, rounded or flexuose, flat, ulcerose or slightly elevated, when erumpent through the bark (Fig. 1). Soredia granular or farinose 17-24 $\mu \mathrm{m}$ diam. Apothecia not seen so far, including the Polish material.

Chemistry. According to Thor (1988), the species produces hydroxyanthraquinone derivatives: parietin (major) and fallacinal (minor). Spot test reactions: thallus C-, K-, PD-; soralia C-, K+ violet-red, PD-.

Ecology. Caloplaca lucifuga was recorded in old oak-lime-hornbeam and oakhornbeam forests in Poland, at sun-exposed or moderately shaded sites with a relatively high air humidity. The species occurred on the bark of old oaks and hornbeams 
(usually with a trunk girth of over $300 \mathrm{~cm}$ ) growing by mid-forest roads, less frequently inside forest communities.

The species was observed on the bark of Quercus robur together with Acrocordia gemmata, Arthonia byssacea, Calicium adspersum, $C$. salicinum, $C$. viride, Chrysothrix candelaris, Cliostomum corrugatum, Lecanora expallens, Lepraria incana, L. vouauxii, Lobaria pulmonaria, Ochrolechia turneri, Pertusaria amara, Phlyctis argena and Ramalina sp. in the Pojezierze Olsztyńskie lakeland.

The group of accompanying taxa in the Puszcza Borecka forest included species such as Buellia griseovirens, Chaenotheca trichialis, Pertusaria albescens, P. coccodes and $P$. hemisphaerica on oaks, as well as Arthonia didyma, A. ruana, Bacidia subincompta, Bacidina assulata, Lecanora intumescens, L. glabrata, Opegrapha varia, O. viridis, Pyrenula laevigata and $P$. nitida on the bark of hornbeams.

According to literature sources, Caloplaca lucifuga clearly prefers the bark of old deciduous trees in woodland tree stands described in different parts of Europe as „wooded pastures” or „wooded meadows” (Thor 1988). Such ecosystems consist of more or less scattered, aged trees and a mosaic of grazing or, less frequently, mowing meadows (Kirby et al. 1995). Known mostly from Scandinavia and Great Britain, they also occur in, for instance, Estonia. These sites have for a long time functioned as extensive pastures and are characterised by a specific ecological continuity. They are important habitats of many rare lichens everywhere (Thor 1988; Laundon 1992; Lepik, Jüriado 2008). C. lucifuga is an indicator species of such areas (Arup 1997; Coppins, Coppins 2002). C. lucifuga also finds similar conditions in very old parks (Thor 1988; Laundon 1992; Hallingbäck 1995). Futhermore, it occurs in denser forests, although usually on the bark of trees growing on the forest edge, e.g. by forest roads.

Caloplaca lucifuga usually colonises deeply cracked bark of very old oaks (Quercus robur, $Q$. petraea) with a breast diameter of 1-2 m. It was observed on the bark of Castanea, Fagus, Tilia and Ulmus considerably less frequently (Thor 1988). The species is also known from the bark of Aesculus hippocastanum (Brunialti et al. 2001; Aptroot et al. 2001), Acer pseudoplatanus (Palice et al. 2003), Carpinus betulus (Lipnicki, pers. comm. 2009; Zalewska 2000), Castanea sativa (Poelt 1994; Lopez De Silanez et al. 1999), Fagus sylvatica (Spier et al. 2008), Tilia cordata (Türk, Wunder 1999) and Ulmus glabra (Berger, Türk 1993). C. lucifuga was also recorded on dead wood (Clerc 2004).

Thor (1988) stresses the species preference for high air-humidity areas (e.g. near lakes, the seaside). He also notes that the lichen mostly grows in deep bark cracks in well-lit sites while it also occurs outside the cracks on flat, raised surfaces, when the shading is greater. The majority of records of $C$. lucifuga from oak bark are reported for trees with natural properties of the periderm, not impregnated with dusts (Thor 1988; Thor, Arvidsson 1999; Ek, Johannesson 2006). Data from more diversified habitats (Bratli, Haugan 1997) suggest a slightly broader ecological amplitude of the species. Based on studies conducted in the Östergötland county in south-east Sweden on sun-exposed precipices overgrown by oaks, Ek et al. (1995) report that the breast diameter of $62 \%$ of old trees with fissured bark colonised by C. lucifuga ranged from 27 to $92 \mathrm{~cm}$. Therefore, the age of the tree and, to a lesser degree, its trunk diameter seem to be major factors conditioning the occurrence of $C$. lucifuga (Thor 1988). 
Caloplaca lucifuga grows in relatively rich epiphytic communities abundant in rare lichen species. Of taxa mostly accompanying $C$. lucifuga on old oaks, Arthonia byssacea, A. vinosa, Buellia violaceofusca, Calicium quercinum, Chaenotheca hispidula, Cliostomum corrugatum, Cyphelium sessile, Lecanographa amylacea, Ramalina baltica incl. obtusata, Schismatomma decolorans and S. pericleum, are particularly interesting (Thor, Arvidsson 1999; Ek, Johannesson 2006). According to Wirth (1995), C. lucifuga is a component of communities of the order Chrysothrichetalia candelaris Wirth, represented by, e.g., numerous „calicioid lichens”.

World distribution. Caloplaca lucifuga occurs mostly in Europe, where it has a broad distribution range. The species in known from Denmark, France, Germany, Sweden, Great Britain and Italy (Thor 1988) as well as from Luxembourg (Diederich 1989), Belgium (Diederich et al. 1991), Estonia (Ekman et al. 1991), Austria (Berger, Türk 1993), Poland (Lipnicki 1993), Portugal (van den Boom and Giralt 1996), Norway (Bratli, Haugan 1997), Finland (Vitikainen et al. 1997), Spain (Etayo 1991), Latvia (Sundin, Thor 1990), the Czech Republic (Palice et al. 2003), Lithuania (Motiejūnaitè et al. 2003), Switzerland (Clerc 2004), Slovakia (Palice et al. 2006), Bulgaria (Spier et al. 2008) and Croatia (Partl 2009).

It seems that the occurrence range of $C$. lucifuga in Europe is related to the distribution of deciduous forests of the temperate zone. Localities of the species in Sweden and Norway in the Scandinavian Peninsula are situated only in its southern part belonging to the nemoral zone. The lichen also occurs in the sub-Mediterranean zone in the south of Europe, probably at localities situated mostly in the mountains (cf. López De Silanes et al. 1999; Brunialti et al. 2001).

Outside Europe, C. lucifuga is known only from South America. Two specimens of the lichen were collected by H. Sipman and J. Aguirre in Columbia (Lichen Herbarium Berlin, BGBM - WWW).

Caloplaca lucifuga is usually known from few localities in individual countries. It is locally very frequent only in southern Sweden (Hultengren 1994; Ek et al. 1995), from where Thor and Arvidsson (1999) report ca 200 localities. On the other hand, Ek and Johannesson (2006) report as many as 400 records (58\% of all records in Sweden) only from the Östergötland county in south-east Sweden. It is also a fairly frequent lichen in the Vosges in France (Aptroot et al. 2001).

REMARKs. As the number of its localities is small, $C$. lucifuga is considered to be vulnerable in many countries. It is classified as critically endangered (CR) in Finland (Rassi et al. 2001) and is believed to be endangered (EN) in Austria (Türk, Haffelner 1999), Denmark (Søchting, Alstrup 2002), Switzerland (Scheiddeger et al. 2002) and the Czech Republic (Liška et al. 2008). It is classified as vulnerable (VU) in Great Britain (Woods, Coppins 2003) and Norway (Timdal et al. 2006). It is thought to be near threatened (NT) in Sweden (Gärdenfors 2005) and Estonia (Randlane et al. 2008). The species has not been red-listed in Poland due to very scarce data (Cieśliński et al. 2006). However, as habitats characteristic of $C$. lucifuga are becoming extinct and the number of its localities is small, the taxon seems to fully deserve to be included in the next edition of the red list.

Distribution in Poland. C. lucifiga is known from ten localities in northern and north-east Poland. It occurs in the Bory Tucholskie forest (Lipnicki 1993), Puszcza Borecka forest (Zalewska 2000), Puszcza Białowieska forest (Sparrius 2003; Cieśliński 2003) and in the Pojezierze Olsztyńskie lakeland (present work) (Fig.2). 


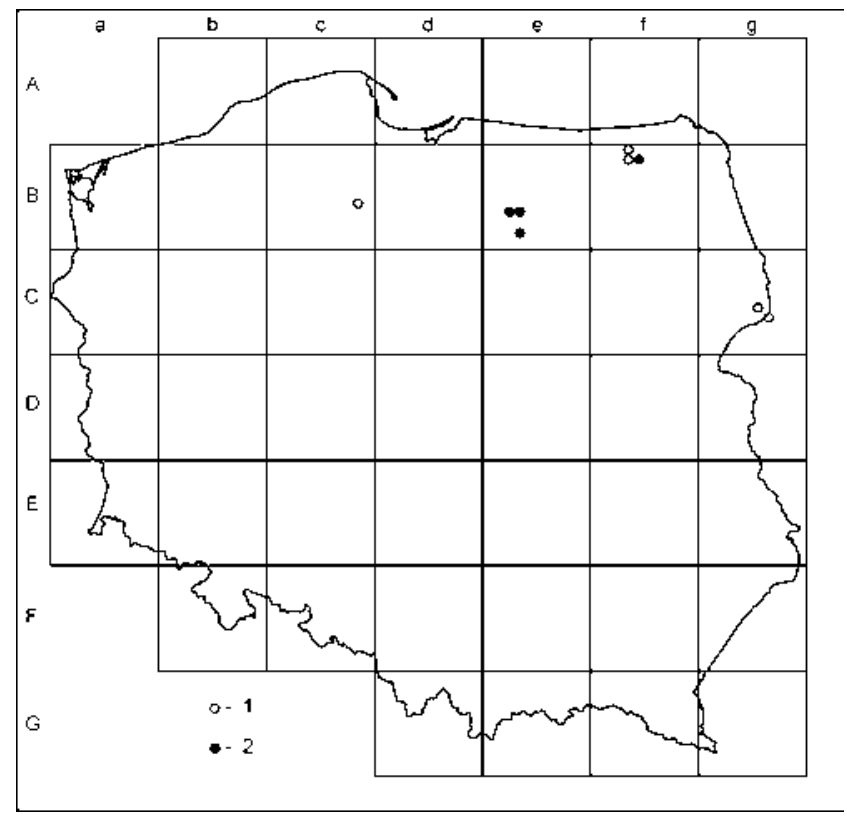

Fig. 2. Distribution of Caloplaca lucifuga in Poland (in the ATPOL square grid): 1 - known records; 2 - new records.

Localities known prior to this paper. ATPOL grid square Bc 58 - Bory Tucholskie forest, vicinity of the 'Krzywe Koło w pętli Wdy' reserve (Lipnicki 1993). Bf 03 and Bf 13 - Pojezierze Ełckie Lakeland, Puszcza Borecka forest (Zalewska 2000; Cieśliński 2003). Cg 55 - Równina Bielska plain: Puszcza Białowieska forest (Cieśliński 2003, locality cited as pers. comm. by J. Nowak). Cg 66 - Puszcza Białowieska forest, Białowieża, Białowieża forest inspectorate, near the road bordering on forest sections Nos 452B and 453A (Sparrius 2003; L. Sparrius, pers. comm. 2009).

Specimens examined. Be 62 - Pojezierze Olsztyńskie lakeland: Las Warmiński nature reserve, forest section No 705d, 5338'59.7'N, 20³0'03.1”E, 8 July 2008, leg. D. Kubiak (OLTC-L 3042). Be 63 - 'Las

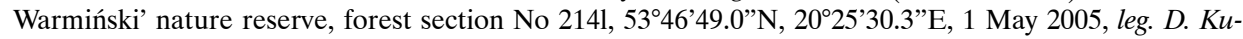
biak (OLTC-L 1864). Be 83 - Pojezierze Olsztyńskie lakeland, 'Dęby Napiwodzkie' nature reserve, 30 July 2008, leg. D. Kubiak (OLTC-L 3227). Bf 03 - Pojezierze Ełckie lakeland, Puszcza Borecka forest, Borki forest inspectorate, Diabla Gora forest district, local square $38,54^{\circ} 08^{\prime} \mathrm{N}, 22^{\circ} 05^{\prime} \mathrm{E}$, at the edge of the oak-lime-hornbeam forest by the 'Dębowa Linia' forest road, 18 July1996, leg. A. Zalewska (OLS-L);

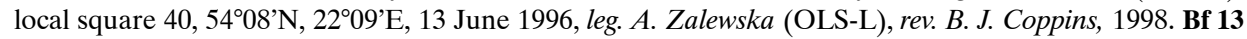
- Puszcza Borecka forest, Borki forest inspectorate, Lipowo forest district, 'Borki' nature reserve, forest

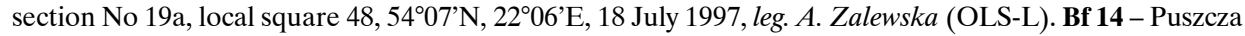
Borecka Forest, Czerwony Dwór forest inspectorate, Rogonie forest district, local square $61,54^{\circ} 06^{\prime} \mathrm{N}$, $22^{\circ} 11^{\prime} \mathrm{E}, 13$ July 1995, leg. A. Zalewska (OLS-L). 


\section{DISCUSSION}

Although it forms diminutive and inconspicuous thalli, Caloplaca lucifuga is a fairly characteristic species. It is distinguished by a pale-grey, very thin endophloedic thallus and delimited soralia, yellow-grey to dirty yellowish-orange-brown reacting with $\mathrm{K}+$ violet-red.

Caloplaca chrysophthalma Degel. bears the greatest resemblance to C. lucifuga. The former differs from Caloplaca lucifuga by having a thicker, epiphloedic thallus, grey to yellow (Thor 1988), yellowish-green, yellow-green or grey (Wetmore 2004), with distinct and delimited, usually bright orange-yellow soralia. It rarely produces immersed, poorly developed thalli with scattered, light yellow soralia (Laundon 1992; Wetmore 2004). Furthermore, C. chrysophthalma produces bright orange apothecia, not always present (Thor 1988; Laundon 1992; Wetmore 2004). Clusters of algal cells, present in C. lucifuga, are absent on cross section (Thor 1988). Both species have slightly different chemical properties. $C$. chrysophthalma also contains parietin (major) as well as additional substances: emodin (minor) and fragilin (minor), instead of fallacinal. Soralia and apothecia react with $\mathrm{K}+$ violet-red. The distribution of both taxa also differs. C. chrysophthalma is mostly known from North America (Wetmore 2004) and from northern Europe, where it occurs in Great Britain (Laundon 1992), Norway (Ihlen 1997) and Denmark, Estonia and Sweden (Thor, Arvidsson 1999). It has few localities in other European countries as well as in Mongolia (cf. sources cited by Culberson et al. 2008) and China (Wetmore 2004). This species has been not recorded in Poland so far (cf. Fałtynowicz 2003). Moreover, Caloplaca chrysophthlma differs from $C$. lucifuga by its ecological preferences. It is usually associated with trees having natural eutrophic or enriched, dusted bark. In Europe, it is known from such phorophytes as Acer, Fraxinus, Tilia, Ulmus or less frequently from Quercus growing in roadside alleys or other open sites (Hallingbäck 1995; Thor, Arvidsson 1999). In North America, it is a forest epiphyte often found on, old trees of Populus tremuloides (Wetmore 2004).

TLC analysis is not helpful in species identification when fine thalli, such as the ones used in this study, with a very low content of accessory substances, are examined (cf. Thor 1988). Thallus thickness and colour as well as the colour of soralia remain major characters differentiating $C$. lucifuga from $C$. chrysophthalma. Habitat data which should, however, be interpreted with care (cf. Bratli, Haugan 1997), may also be useful. It seems that some characters in the descriptions of the morphology and ecology (Thor 1988; Laundon 1992; Wetmore 2004) of both representatives of the genus Caloplaca slightly overlap. The lack of more extensive data available on the frequency of chemical substances recorded and their influence on the colour of soralia as well as data on the structure of fruitbodies and picnidia, not found in C. lucifuga so far, causes some confusion. More wide-ranging chemo-taxonomic examinations of very large collections belonging to 400 records from Östergötland (Ek, Johannesson 2006) and from North America (405 collections, see Wetmore 2004) could be helpful. An analysis of the genetic similarity of both taxa could also provide interesting results.

Buellia violaceofusca Thor \& Muhr, another sorediate species, can be found together with Caloplaca lucifuga on old oak trees growing in forests. The former has a similar, pale grey endophloedic thallus with slightly elevated soralia, often confluent 
and clearly darker, brown tinged violet. The species is known to be sterile (apothecia and picnidia have not been observed). All spot test reactions on the thallus and soralia of B. violaceofusca are negative (Thor, Muhr 1991).

It is finally worth mentioning that the status of $C$. lucifuga is not clear since, similarly to many other sterile representatives, the species was placed in the genus Caloplaca mostly based on the presence of antraquinones, parietin and fallacinal. These substances occur together with emodin also in other Teloschistales belonging to chemosyndrome A (Arup, Grube 1999). Based on molecular studies, Søchting and Lutzoni (2003) have recently shown that the morphological form of the thallus and the development type of its lower cortex are not good taxonomic characters differentiating the genera Caloplaca, Xanthoria and Fulgensia. It was proven that, for instance, some species of the genus Caloplaca with crustose thalli should be transferred to the genus Xanthoria.

\section{CONCLUSIONS}

Based on the current knowledge on the identification and ecology of C. lucifuga and $C$. chrysophthalma as well as the distribution rate of characteristic habitats preferred by them, it may be suggested that Caloplaca lucifuga is considerably more widespread in Poland but has been poorly differentiated (cf. Wirth 1997). Detailed observations of old oak tree stands, especially within large forest complexes in NE Poland, should be conducted. It seems possible that $C$. chrysophthalma could also be found in Poland.

Acknowledgements. The authors are indebted to B. J. Coppins (Edinburgh) for the confirmation of identification of specimen from the Puszcza Borecka forest. We would like to express our sincere thanks to S. Cieśliński (Kielce), L. Lipnicki (Gorzów Wlkp.) and L. Sparrius (Gouda) for the detailed data on localities they supplied. Data were used for mapping. The anonymous reviewer is warmly thanked for valuable comments on the manuscript.

\section{REFERENCES}

Aptroot A., Sparrius L., Herk van K., Bruyn de U. 2001. Origin and distribution of recently described lichens from the Netherlands. Aktuelle Lichenologische Mitteilungen, NF 5: 13-25. http://www.almneu.de/NF5/ALM-NF5.pdf

Arup U. 1997. Skoglig kontinuitet. (In:) U. Arup, S. Ekman, I. Kärnefelt, J.-E. Mattsson (eds). Skyddsvärda lavar i sydvästra Sverige. SBF-förlaget, Lund: $92-95$.

Arup U., Grube M. 1999. Where does Lecanora demissa (Ascomycota, Lecanorales) belong? Lichenologist 31: 419-430.

Berger F., Türk R. 1993. Neue and seltene Flechtenund lichenicole Pilze aus Oberösterreich. Linzer Biol. Beitr. 25 (1): 167-204.

Boom van den P. P. G., Giralt M. 1996. Contribution to the flora of Portugal, lichens and lichenicolous fungi I. Nova Hedwigia 63 (1-2): 145-172.

Bratli H., Haugan R. 1997. Caloplaca lucifuga new to Norway. Graphis Scripta 8: 41-43.

Brunialti G., Giordani P., Benesperi R., Ravera S. 2001. Addition to the lichen flora of the Ligurian Apennines (NW Italy). Webbia 56 (1): 223-228.

Cieśliński S. 2003. Atlas rozmieszczenia porostów (Lichenes) w Polsce Północno-Wschodniej. Phytocoenosis 15 (N.S.). Suppl. Cartogr. Geobot. 15: 1-426. 
Cieśliński S., Czyżewska K., Fabiszewski J. 2006. Red list of the lichens in Poland. (In:) Z. Mirek, K. Zarzycki, W. Wojewoda, Z. Szeląg (eds). Red list of plants and fungi in Poland. W. Szafer Institute of Botany, Polish Academy of Sciences, Kraków: 71-89.

Cieśliński S., Fałtynowicz W. 1993. Note from editors. (In:) S. Cieśliński, W. Fałtynowicz (eds), Atlas of the geographical distribution of lichens in Poland. 1. W. Szafer Institute of Botany, Polish Academy of Sciences, Kraków: 7-8.

Clerc P. 2004. Les champignons lichénisés de Suisse. Cryptogamica Helvetica 19: 1-320.

Coppins A. M., Coppins B. J. 2002. Indices of ecological continuity for woodland epiphytic lichen habitats in the British Isles. British Lichen Society, London.

Culberson, W. L., Egan, R. S., Esslinger, T. L. 2008. Recent literature on lichens. [Presented on the Web by E. Timdal.; latest update 2009.03.02.] http:/www.nhm.uio.no/cgi-bin/rll.pl?sq=0\&au=\&fr=15 $36 \&$ to $=2008 \& \mathrm{jo}=\& \mathrm{t} 1=\& \mathrm{t} 2=\& \mathrm{t} 3=\& \mathrm{t} 4=\& \mathrm{t} 5=\& \mathrm{casc}=\& \mathrm{gen}=$ caloplaca $\&$ epi $=$ chrysophthalma $\& \mathrm{t}$ $\mathrm{p}=-\&$ down $=\mathrm{N} \& \mathrm{r} 0=\& \mathrm{r} 1=\& \mathrm{rn}=\& \mathrm{ws}=\mathrm{w} \& d \mathrm{dia}=0 \& \mathrm{st}=\mathrm{a} \& \mathrm{fo}=\mathrm{s} \& \mathrm{RLL}=\mathrm{x} \& M a t=\mathrm{x} \&$ Supl $=[7 \mathrm{Sept}$. 2009].

Diederich P. 1989. Les lichens épiphytiques et leurs champignons lichénicoles (macrolichens exceptés) du Luxembourg. Trav. Scient. Musée Nat. Hist. Natur. Luxembourg 14: 1-268.

Diederich P., Ertz D., Stapper N., Sérusiaux E., Broeck van den D., Boom van den P., Ries C. 2009. The lichens and lichenicolous fungi of Belgium, Luxembourg and northern France. http://www.lichenology.info [2 Oct. 2009].

Diederich P., Sérusiaux E., Boom van den P. 1991. Lichens et champignons lichénicoles nouveaux ou intéressants pour la flore de la Belgique et des régions voisines. V. Lejeunia n. S. 136: 1-47.

Ek T., Johannesson J. 2006. Multi-purpose management of oak habitats. Examples of best practice from the county of Östergötland, Sweden. Norrköpings Tryckeri, Norrköping.

http://www.advantagehardwood.org/files/Multi_purpose_management_oak_habitats_planning.pdf

Ek T., Wadstein M., Johanneson J. 1995. Varifrån kommer lavar knutna till gamla ekar? [What is the origin of lichen flora of old oaks?]. Svensk Bot. Tidskr. 89: 335-343.

Ekman S., Fröberg L., Kärnefelt I., Sundin R., Thor G. 1991. New or interesting lichens from Estonia. Folia Cryptog. Estonica 28: 5-25.

Etayo J. 1991. Dos especies de líquenes recientemente, encontradas en Navarra (España). Collectanea Botanica [Barcelona] 20: 251-253.

Fałtynowicz W. 2003. The lichens, lichenicolous and allied fungi of Poland - an annotated checklist. W. Szafer Institute of Botany, Polish Academy of Sciences, Kraków.

Gärdenfors U. (ed.). 2005. Rödlistade arter i Sverige 2005. ArtDatabanken, SLU, Uppsala.

Hallingbäck T. 1995. Ekologisk katalog över lavar. ArtDatabanken, Uppsala..

Hultengren S. 1994. Nya eller intressanta epifytiska lavar från sydvästra Sverige [New or interesting epiphytic lichens from southwestern Sweden]. Graphis Scripta 7: 43-47.

Ihlen P. G. 1997. Contribution to the Norwegian flora of lichens and lichenicolous fungi. Graphis Scripta 8: 33-39.

Kirby K. J., Thomas R. C., Key R. S., McLean I. F. G., Hodgetts N. G. 1995. Pasture-woodland and its conservation in Britain. Biological Journal of the Linnean Society 56 (Suppl.): 135-153.

Kukwa M. 2005a. Nowe stanowiska rzadkich i interesujących porostów na Pomorzu Gdańskim. Część II. Sorediowane i izydiowane porosty skorupiaste. Acta Bot. Cassub. 5: 113-125.

Kukwa M. 2005b. Lecanora thysanophora (Lecanoraceae, zlichenizowane Ascomycota) w Polsce. Fragm. Florist. Geobot. Polonica 12 (2): 385-391.

Kukwa M. 2006. The lichen genus Lepraria in Poland. Lichenologist 38 (4): 293-305.

Kukwa M., Kubiak D. 2007. Six sorediate crustose lichens new to Poland. Mycotaxon 102: 155-164.

Kukwa M., Szymczyk R. 2006. Stanowiska porostu Mycobilimbia epixanthoides (Ascomycota lichenisati) na północy Polski. Fragm. Florist. Geobot. Polonica 13 (2): 429-432.

Laundon J. R. 1992. Caloplaca Th. Fr. (1860). (In:) O. W. Purvis, B. J. Coppins, D. L. Hawksworth, P. W. James, D. M. Moore (eds), The Lichen Flora of Great Britain and Ireland: 141-159. Natural History Museum Publications with the British Lichen Society, London.

Leppik E, Jüriado I. 2008. Factors important for epiphytic lichen communities in wooded meadows of Estonia. Folia Cryptog. Estonica 44: 75-87.

Lichen Herbarium Berlin, Catalouge No. 89429 \& 90708, H. Sipman \& J. Aguirre. http://us.mirror.gbif. org/occurrences/searchWithTable.htm?c[0].s $=20 \& c[0] . p=0 \& c[0] . o=14379367 \& c[1] . s=19 \& c[1]$. $\mathrm{p}=0 \& \mathrm{c}[1] . \mathrm{o}=75.0 \mathrm{~W}, 5.0 \mathrm{~N}, 73.0 \mathrm{~W}, 6.0 \mathrm{~N}$ [6 October. 2009]. 
Lipnicki L. 1993. Stan flory porostów Borów Tucholskich jako wskaźnik potrzeby ochrony tego kompleksu leśnego. (In:) M. Rejewski, A. Nienartowicz, M. Boiński (eds). Tuchola Forest. Natural valueConservation-Future, Post-conference papers. III Conference Complex nature conservation of the region: biosphere reserve "Bory Tucholskie". UMK, Toruń: 340-345.

Liška J., Palice Z., Slavíková Š. 2008. Checklist and Red List of lichens of the Czech Republic. Preslia 80: 151-182.

López De Silanes M. E., Paz-Bermúdez G., Etayo J., Terrón A. 1999. Aportación al catálogo de líquenes del Parque Nacional de Los Picos de Europa, N de España. Nova Acta Ci. Compostelana Biol. 9: 83-98.

Motiejūnaitė J., Kukwa M., Czarnota P., Prigodina-Lukošienė I., Himelbrant D., Kuznetsova E., Kowalewska A., 2003. Lichens and allied fungi collected during the 15th Symposium of Baltic Mycologists and Lichenologists in Birštonas, Lithuania. Botanica Lithuanica 9 (2): 109-119.

Nordén B. Paltto H., Götmark F., Wallin K. 2007. Indicators of biodiversity, what do they indicate? - Lessons for conservation of cryptogams in oak-rich forest. Biological Conservation 135: 369-379.

Nowak J., Tobolewski Z. 1975. Porosty polskie. PWN, Warszawa-Kraków.

Orange A., James P. W., White F. J. 2001. Microchemical methods for the identification of lichens. British Lichen Society.

Palice Z., Czarnota P., Kukwa M., Kocourková J., Berger F., Guttová A., Halda J., Peksa O., Uhlík P. Svoboda D. 2003. Lišejníky zaznamenané během 9. jarního setkání bryologicko-lichenologické sekce v Hajnici u Mirochova (CHKO Třeboňsko, 11.-14.IV. 2002) [Lichens recorded during the 9th spring meeting of the Bryological-Lichenological Section in Hajnice near Mirochov, South Bohemia]. Bryonora 32: 7-17.

Palice Z., Guttová A., Halda J. 2006. Lichens new for Slovakia collected in the National Park Muránska planina (W Carpathians). ( In:) A. Lackovičová, A. Guttová, E. Lisická, P. Lizoň (eds). Central European lichens - diversity and threat, Mycotaxon Ltd., Ithaca: 179-192.

Partl A. 2009. Checklist of lichens and lichenicolous fungi of Croatia. University of Osijek, Croatia, Preliminary version 1 March 2009. http://www.biologie.uni-hamburg.de/checklists/lichens/europe/ croatia_1.htm [03 September 2009].

Poelt J. 1994. Bemerkenswerte Flechten aus Österreich, insbesondere Steiermark. Mitt. Naturwiss. Ver. Steiermark 124: 91-111.

Purvis O. W., Coppins B. J., Hawksworth D. L., James P. W., Moore D. M. (eds). 1992. The lichen flora of Great Britain and Ireland. Natural History Museum Publications with the British Lichen Society, London.

Randlane T., Jüriado I., Suija A., Lõhmus P., Leppik E. 2008. Lichens in the new Red List of Estonia. Folia Cryptog. Estonica 44: 113-120.

Rassi P., Allanen A., Kanerva T., Mannerkoski I. (eds). 2001. The 2000 Red List of Finish species. Ministry of the Environment \& Finnish Environment Institute, Helsinki.

Rose F. 1992. Temperate forest management: its effect on bryophyte and lichen habitats. (In:) W. Bates, A. M. Farmer (eds). Bryophytes and lichens in a changing environment, Clarendon Press, Oxford: 211-233.

Scheidegger C., Clerc P., Dietrich M., Frei M., Groner U., Keller C., Roth I., Stofer S., Vust M. 2002. Rote Liste der gefährdeten Arten der Schweiz: Baum- und erdbewohnende Flechten. Bern, Bundesamt für Umwelt, Wald und Landschaft BUWAL; Birmensdorf, Eidgenössische Forschungsanstalt WSL.

Søchting U, Alstrup, V., 2002. Danish Lichen Checklist. Ver. 2. Botanical Institute, University of Copenhagen, Copenhagen. www.bi.ku.dk/lichens/dkchecklist/ [7 September 2009].

Søchting U., Lutzoni F. 2003. Molecular phylogenetic study at the generic boundary between the lichenforming fungi Caloplaca and Xanthoria (Ascomycota, Teloschistaceae). Mycol. Res. 107 (11): 12661276.

Sparrius L. B. 2003. Contribution to the lichen floras of the Białowieża Forest and the Biebrza Valley (Eastern Poland). Herzogia 16: 155-160.

Spier L., Dort van K., Fritz Ö. 2008. A contribution to the lichen mycota of old beech forests in Bulgaria. Mycologia Balcanica 5: 141-146.

Sundin R, Thor G. 1990. Some lichens from Latvia. Graphis Scripta 3: 20-23.

Śliwa L. 1996. Note on Mycoblastus fucatus [=M. sterilis] (Lichenes, Mycoblastaceae) from Poland. Fragm. Florist. Geobot. 41 (1): 491-492. 
Śliwa L., Tønsberg T. 1995. The first record of Fuscidea pusilla (Lichenes, Fuscideaceae) for Poland. Fragm. Florist. Geobot. 40 (2): 781-784.

Thor G. 1988. Caloplaca lucifuga: a new lichen species from Europe. Lichenologist 20 (2): 175-178.

Thor G., Arvidsson L. 1999. Rödlistade lavar i Sverige. Artfakta. ArtDatabanken, SLU, Uppsala.

Thor G., Muhr L-E. 1991. Buellia violaceofusca, a new lichen from Sweden. Lichenologist 23 (1): 11-13.

Timdal E., Bratli H., Haugan R., Holien H., Tønsberg T. 2006. Lav 'Lichenes'. (In:) J. A. Kålås, A. Viken, T. Bakken. (eds). 2006. Norsk Rødliste [Norwegian Red List], Artsdatabanken, Norway: 129-140.

Türk R., Haffelner J. H. 1999. Rote Liste gefährdeter Flechten (Lichenes) Österreichs. 2. Fassung. (In:) H. Niklefeld et al. (eds). Rote Listen gefährdeter Pflanzen Österreichs. 2 Auflage. Grüne Reihe des Bundesministeriums für Umwelt, Jugend und familie, 10. Austria Medien Service, Graz: 187-228.

Türk R., Wunder H. 1999. Die flechten des Nationalparks Berchtesgaden und angrenzeder Gebiete. Berchtesgaden, Nationalpark Berchtesgaden, Forschungsbericht 42. Nationalparkverwaltung Berchtesgaden.

Vitikainen O., Ahti T., Kuusinen M., Lommi S., Ulvinen T. 1997. Checklist of lichens and allied fungi of Finland. Norrlinia 6: 1-123.

Wetmore C. M. 2004. The sorediate corticolous species of Caloplaca in North and Central America. Bryologist 107 (4): 505-520.

Wirth V. 1995. Die Flechten Baden-Württembergs. Ulmer, Stuttgart.

Wirth V. 1997. Einheimisch oder eingewandert? Über die Einschätzung von Neufunden von Flechten. (In:) L. Kappen (ed.). New species and novel aspects in lichenology and physiology of lichens. In honour of O. L. Lange. Biblioth. Lichenol. 67: 277-289.

Woods R. G., Coppins B. J. 2003. A conservation evaluation of British lichens. British Lichen Society, London.

Zalewska A. 2000. Ekologia porostów Puszczy Boreckiej i jej obrzeży. Doctoral Thesis. University of Warmia and Mazury in Olsztyn, $178 \mathrm{pp}$. and Atlas, $302 \mathrm{pp}$.

\section{Uwagi o występowaniu Caloplaca lucifuga (Teloschistales, Ascomycota) w Polsce}

\section{Streszczenie}

Caloplaca lucifuga jest porostem znanym z Europy oraz z dwóch niepublikowanych notowań z Ameryki Południowej (Kolumbia). Pomimo szerokiego zasięgu występowania na kontynencie europejskim, gatunek ten podawany jest w poszczególnych krajach zwykle z niewielu stanowisk. W Polsce zarejestrowany został łącznie na dziesięciu stanowiskach w północnej i północno-wschodniej części kraju. W pracy przedstawiono dotychczas znane oraz nowe stanowiska tego gatunku stwierdzone w latach 2005-2008 na Pojezierzu Olsztyńskim. Uzyskane wyniki oraz przegląd danych dotyczących ekologii tego gatunku wskazują, iż może być on bardziej rozpowszechniony w dużych kompleksach leśnych z udziałem starych drzew liściastych, zwłaszcza dębów. Ze względu jednak na zanikanie siedlisk charakterystycznych dla $C$. lucifuga, gatunek ten zasługuje na umieszczenie go na krajowej „Czerwonej Liście” porostów zagrożonych wymarciem. Porost ten ma potencjalne właściwości lichenoindykacyjne, dotychczas w Polsce niewykorzystane, mogące mieć zastosowanie w wyznaczaniu miejsc o wysokiej bioróżnorodności oraz najcenniejszych zbiorowisk leśnych. Epifit ten, pomimo drobnych rozmiarów ma bardzo charakterystyczne cechy morfologiczne i chemiczne pozwalające odróżnić go od innych podobnych taksonów. Najbardziej istotne cechy diagnostyczne tego gatunku to jasnoszara, endofloedyczna plecha oraz liczne, zaokraglone lub nieregularne, nie zlewające się ze sobą, jasnożółtawe, żółtawoszare do brudno żółto-pomarańczowo-brunatnych soralia, barwiące się od $\mathrm{KOH}$ na karminowo-czerwono. 


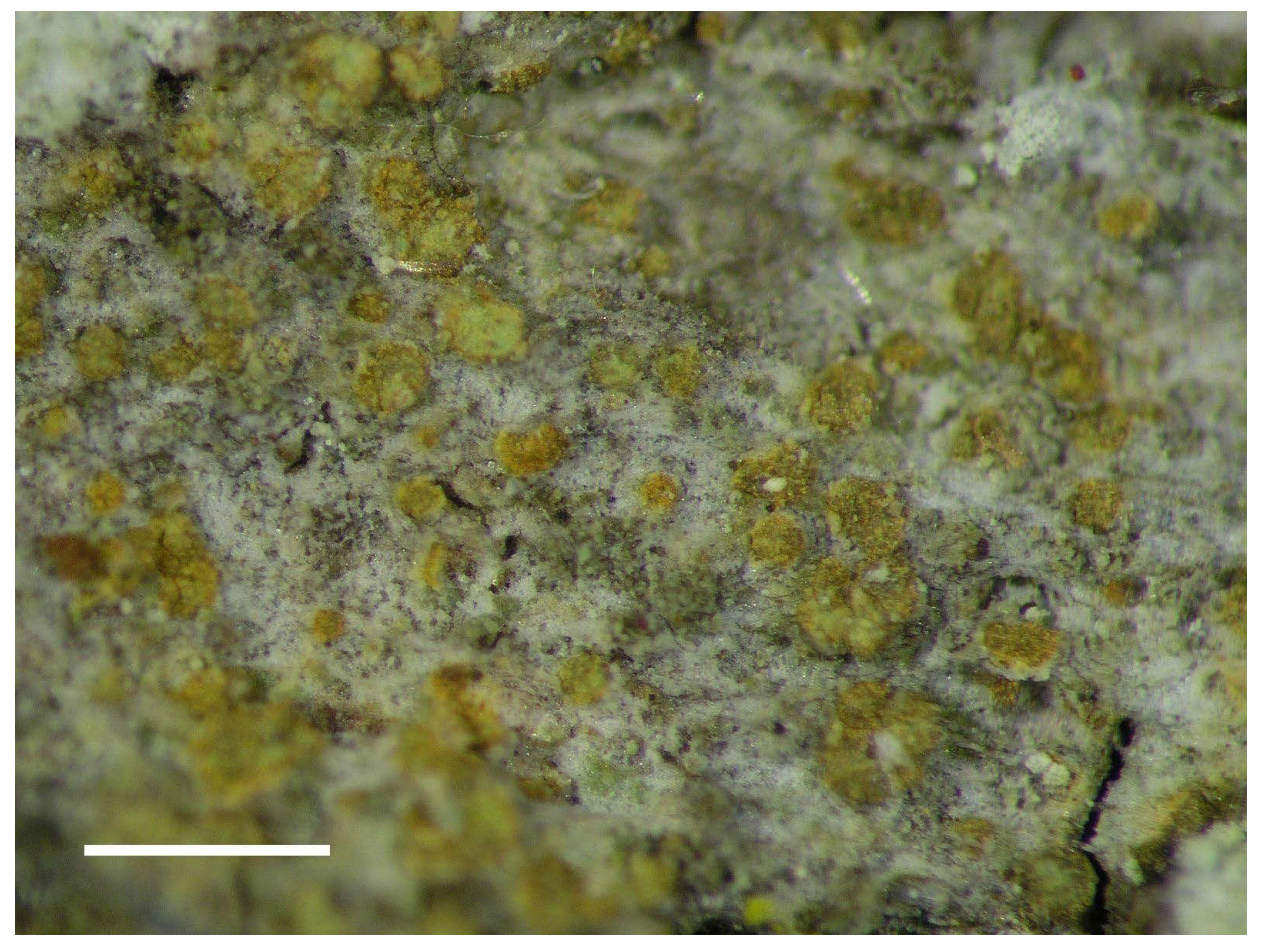

Fig. 1. Habit of Caloplaca lucifuga (OLTC-L 3227); scale bar $=1 \mathrm{~mm}$. 